\title{
PENGARUH UKURAN KAP, AUDIT FEE, DAN UKURAN PERUSAHAAN TERHADAP KUALITAS AUDIT (Studi Empiris pada Perusahaan Manufaktur Sektor Industri Barang Konsumsi Terdaftar di Bursa Efek Indonesia Periode 2015-2019)
}

\author{
Martiya Indriyani ${ }^{1}$ \\ Zumratul Meini² \\ Program Studi Akuntansi, Fakultas Ekonomi dan Bisnis Universitas Nasional ${ }^{1,2}$ \\ Email: zum.meini@gmail.com ${ }^{1}$
}

\begin{abstract}
This study aims to examine the effect of KAP size, audit fee, and firm size on audit quality. This study uses data from 25 companies in the consumer goods industry sector listed on the Indonesia Stock Exchange for the 2015-2019 period as samples using the purposive sampling method in determining the sample. The results of the study show that the size of the KAP has a positive effect on audit quality. Auditors who are members of KAP big 4 have good skills, high integrity, and have good characteristics so that they can support improving audit quality. Audit Fee has a positive effect on audit quality, the high fee given will increase the intensity of auditors in planning higher audit quality. Firm size has no effect on audit quality, this shows that the size of the company does not determine audit quality.
\end{abstract}

Keyword: Public Accounting Firm Size (KAP Size), audit fees, company size, audit quality

\begin{abstract}
ABSTRAK
Penelitian ini bertujuan untuk menguji pengaruh ukuran KAP, audit fee, dan ukuran perusahaan terhadap kualitas audit. Penelitian ini menggunakan data 25 perusahaan sektor industri barang konsumsi terdaftar di Bursa Efek Indonesia periode 2015-2019 sebagai sampel dengan metode purposive sampling dalam penentuan sampelnya. Hasil penelitian menunjukkan ukuran KAP berpengaruh positif terhadap kualitas audit. Auditor yang tergabung di KAP big 4 memiliki kecakapan yang baik, integritas yang tinggi, dan memiliki karakteristik yang baik sehingga bisa mendukung peningkatan kualitas audit. Audit Fee berpengaruh positif terhadap kualitas audit, tingginya fee yang diberikan akan meningkatkan intensif auditor dalam melakukan perencanaan kualitas audit yang lebih tinggi. Ukuran perusahaan tidak berpengaruh terhadap kualitas audit, hal ini menunjukkan besar kecilnya ukuran perusahaan tidak menentukan kualitas audit.

Kata Kunci: Ukuran Kantor Akuntan Publik (KAP), audit fee, ukuran perusahaan, kualitas audit
\end{abstract}




\section{PENDAHULUAN}

Laporan Keuangan perusahaan menunjukkan kinerja yang berhasil dicapai oleh manajemen dalam menjalankan usahanya. Laporan keuangan merupakan aspek penting dalam suatu proses bisnis karena menunjukkan informasi-informasi yang sangat dibutuhkan oleh para stakeholder dalam rangka mengambil keputusan penting, baik keputusan ekonomi, politik, dan sosial (Darwin, 2012). Dengan demikian, laporan keuangan yang telah dibuat perusahaan menjadi salah satu bentuk pertanggungjawaban manajemen kepada pihak-pihak yang berkepentingan tadi. Banyaknya kepentingan yang harus diputuskan atas dasar laporan keuangan tersebut menyebabkan profesi akuntan memegang peranan penting dan memiliki pengaruh yang luas bagi masyarakat (Nurhayati \& Dwi, 2015).

Untuk meningkatkan kredibilitas dari suatu laporan keuangan, hal yang utama dan penting untuk diperhatikan adalah bagaimana peran auditor dalam mengaudit laporan keuangan perusahaan. Semakin tinggi kualitas audit yang dihasilkan oleh auditor maka akan dapat meningkatkan kepercayaan pengguna laporan keuangan (Kurniasih, 2014 dalam Nurhayati \& Dwi, 2015). Oleh karena itu, auditor dituntut untuk bekerja secara profesional dan melandaskan pekerjaan mereka pada standar atau peraturan yang berlaku dan juga kode etik akuntan publik (Nurhayati \& Dwi, 2015).

Beberapa tahun terakhir ini, permasalahan terkait rendahnya kualitas audit yang melibatkan seorang auditor menjadi perhatian masyarakat luas (Agusti \& Pertiwi, 2013). Kualitas audit adalah sebuah kemungkinan auditor akan mendeteksi dan melaporkan salah saji pada laporan keuangan yang disajikan oleh kliennya (Panjaitan, 2018). Kasus mengenai Audit yang belakangan terjadi dan cukup menjadi perhatian besar dari masyarakat luas antara lain adalah kasus laporan keuangan PT. Garuda Indonesia (Persero) Tbk. Kasus terkait kejanggalan laporan keuangan PT Garuda Indonesia (Persero) Tbk. tahun buku 2018 menunjukkan bahwa dalam pemeriksaan yang telah dilakukan terdapat dugaan pelanggaran berat yang dilakukan terkait opini yang diberikan oleh pihak akuntan publik.

Skandal-skandal yang terjadi di Indonesia berdampak terhadap kepercayaan masyarakat luas tentang kualitas audit yang dihasilkan. Hal ini menjadi menarik untuk diteliti, apa saja faktor yang dapat menyebabkan kualitas audit menjadi menurun. Banyak penelitian mencoba mengukur kualitas audit dengan berbagai model. De Angelo (1981) dalam Darwin (2012) mendefinisikan kualitas audit sebagai kemungkinan dimana seorang auditor menemukan tentang adanya kesalahan dan pelanggaran dalam sistem akuntansi kliennya. 
Beberapa penelitian tentang kualitas audit telah banyak dilakukan antara lain oleh Calocha \& Herwiyanti (2020); Muhamad Taqi et al. (2020); dan AL-Qatamin \& Salleh (2020) yang menunjukkan bahwa kualitas audit akan dipengaruhi oleh beberapa faktor, yaitu dari faktor internal (yaitu dari diri auditor sendiri, antara lain pengalaman, profesionalisme, tekanan anggaran, audit tenur, dan pengetahuan dalam mendeteksi kesalahan), dan juga faktor eksternal (yaitu dari sisi client, misalnya besar kecilnya perusahaan klien atau feeyang diberikan). Faktor yang masih menarik untuk diteliti salah satunya yaitu kompetensi dan juga independensi kantor akuntan yang ditunjukkan dengan ukuran KAP yang digunakan perusahaan (Widiastuty, 2010). Penelitian yang dilakukan oleh Sari (2014) menunjukkan bahwa ukuran KAP memiliki pengaruh positif terhadap kualitas audit karena terdapat kecenderungan KAP berukuran besar, yaitu KAP the big four, untuk menyajikan hasil audit yang lebih berkualitas karena memiliki nama baik yang dipertaruhkan dan jumlah sumberdaya dalam jumlah besar sehingga dapat melakukan prosedur audit dengan lebih cepat dan efisien. Perusahaan yang menggunakan jasa dari KAP berukuran besar cenderung untuk dapat lebih dipercaya oleh masyarakat luas (Sari, 2014). Namun Rizaldi (2017) berpendapat bahwa kualitas audit yang diberikan tidak dipengaruhi oleh Ukuran KAP karena setiap auditor yang bekerja pada KAP kecil maupun besar merupakan seorang akuntan publik yang sudah memenuhi standar kompetensi dan telah mendapatkan izin untuk melakukan prosedur audit sesuai dengan undang-undang yang berlaku (Rizaldi, 2017).

Selain ukuran KAP, audit fee juga merupakan salah satu faktor yang dapat mempengaruhi kualitas audit. Audit fee adalah biaya audit yang diterima oleh auditor setelah melakukan jasa audit (Mulyadi, 2008:63 dalam Ivan, 2020). Besar kecilnya fee yang dikeluarkan beragam tergantung dari risiko penugasan, kompleksitas jasa audit yang diberikan, tingkat keahlian yang dibutuhkan untuk melaksanakan jasa audit tersebut, struktur biaya KAP yang bersangkutan, atau pertimbangan profesional lainnya (Ivan, 2020). Audit fee yang tinggi yang diberikan perusahaan kepada auditor dapat membuat auditor menyetujui tekanan dari klien dan berdampak pada kualitas audit yang dihasilkan (Wicaksono, 2019). Di sisi lain Erieska (2019) menemukan bahwa audit fee tidak berpengaruh terhadap kualitas audit yang dihasilkan oleh auditor. Pemberian fee tidak dapat memastikan baik atau tidaknya kualitas audit yang dihasilkan. Kualitas audit yang dihasilkan dapat dilihat dari auditor yang melakukan audit bukan besarnya feeyang diberikan sehingga audit fee tidak memiliki pengaruh terhadap kualitas audit yang dihasilkan (Erieska, 2019). Hal tersebut didukung oleh penelitian Yakin (2020) karena para auditor bekerja dengan profesional sesuai dengan standar yang sudah ditentukan. 
Kantor Akuntan Publik tempat auditor bernaung juga tentu telah mempunyai standar fee yang harus diterima oleh auditor serta adanya kode etik yang mengikat auditor dalam menjalankan tugasnya (Yakin, 2020).

Selain kedua faktor yang disebutkan sebelumnya, Kualitas audit juga dapat dipengaruhi oleh ukuran perusahaan. Perusahaan yang besar dianggap mempunyai kemampuan yang baik untuk mengelola perusahaan dan menghasilkan laporan keuangan berkualitas. Kemudian, perusahaan berukuran besar juga memiliki kecenderungan untuk menggunakan jasa auditor besar yang lebih independen dan profesional untuk menghasilkan audit yang lebih berkualitas (Sari, 2014). Ukuran perusahaan juga dianggap memiliki pengaruh positif terhadap kualitas audit karena semakin besar perusahaan maka akan memiliki sistem pengendalian internal yang semakin baik, sehingga akan meningkatkan kualitas audit yang dihasilkan seiring dengan mudahnya auditor untuk memperoleh dan memeriksa informasi yang dibutuhkan (Buchori \& Budiantoro, 2019).

Menurut Paramita \& Latrini (2015) ukuran perusahaan tidak memiliki pengaruh terhadap kualitas audit yang dihasilkan, Ia mengatakan bahwa sistem pengendalian internal yang baik tidak ditentukan dengan besar kecilnya ukuran perusahaan. Kasus kecurangan yang pernah terjadi pada PT Kimia Farma Tbk tahun 2002 dimana direksi lama melakukan penggelembungan laba pada perusahaan, hal tersebut menunjukkan perusahaan besar belum tentu memiliki sistem pengendalian internal yang baik, karena dengan sistem pengendalian intern yang ada manajemen tidak mampu atau ikut andil dalam penggelembungan tersebut (Paramita \& Latrini, 2015).

Masih adanya perbedaan hasil penelitian terdahulu menjadi menarik untuk diteliti Kembali, faktor apa yang dapat menentukan tinggi rendahnya kualitas audit suatu perusahaan. Penelitian ini bertujuan untuk menganalisis bagaiman pengaruh ukuran KAP, audit fee, dan ukuran perusahaan terhadap kualitas audit.

\section{KAJIAN TEORI DAN PENGEMBANGAN HIPOTESIS}

\section{Teori Keagenan (Agency Theory)}

Teori Keagenan (Agency Theory) adalah sebuah teori yang menjelaskan tentang hubungan kontraktual yang terjadi antara seseorang yang dipekerjakan (agent) dengan pemilik (principal) yang melakukan pendelegasian wewenang kepada agen dan menerima pemberian suatu jasa dari agen, dimana pada hubungan keagenan tersebut terdapat kontrak antara prinsipal dan agen yang mengharuskan adanya pemberian jasa kepada pihak prinsipal. (Jensen dan Meckling, 1976 dalam Yolanda, Stephanie; Arza, 
2019). Dalam teori keagenan ini dinyatakan bahwa agency cost timbul akibat adanya konflik kepentingan yang terjadi antara prinsipal yang melibatkan agen untuk menerima pendelegasian wewenang dalam pengambilan sebuah keputusan. Oleh karena itu, memonitor agen harus dilakukan agar segala tindakan dilakukan sesuai dengan kepentingan prinsipal (Kristanti, 2014).

Dengan adanya konflik kepentingan tersebut, menyebabkan perlunya peran seorang auditor. Auditor disini berperan sebagai pihak eksternal dengan harapan dapat menjembatani kepentingan antara pihak agen dengan prinsipal. Sikap profesionalisme dan kejujuran auditor sangat diperlukan karena tanggung jawabnya untuk memberikan opini audit yang sesuai dengan keadaan sebenarnya dalam perusahaan (Oktavinarni, 2018).

\section{Kualitas Audit}

Tujuan suatu audit ialah meningkatkan tingkat kepercayaan dari pemakai laporan keuangan yang dituju, terhadap laporan keuangan itu. Tujuan itu dicapai dengan pemberian opini oleh auditor mengenai apakah laporan keuangan disusun, dalam segala hal yang material, sesuai dengan kerangka pelaporan keuangan yang berlaku. Suatu audit yang dilaksanakan sesuai dengan standar audit dan persyaratan etika yang relevan memungkinkan auditor memberikan pendapat tersebut (Tandiotong, 2015).

Untuk memastikan bahwa audit yang dihasilkan berkualitas, seorang auditor yang memiliki sikap profesional akan melakukan prosedur audit dengan benar dan juga cenderung untuk menyelesaikan tahap-tahap proses audit dengan lengkap dan mempertahankan sikap skeptisme dalam melakukan pertimbangan atas bukti-bukti audit yang ditemukan kurang memadai selama melakukan proses audit (Ardini, 2010 dalam Gustiawan, 2015). Kualitas audit adalah sebuah kemungkinan auditor akan mendeteksi dan melaporkan salah saji pada laporan keuangan yang disajikan oleh kliennya. Kualitas audit yang baik akan meningkatkan reliabilitas laporan keuangan dan memberikan manfaat kepada investor, sebab investor dapat membuat keputusan yang lebih tepat atas informasi yang diperoleh dari laporan keuangan perusahaan tersebut. (Panjaitan, 2018).

\section{Ukuran Kantor Akuntan Publik}

Pengertian ukuran KAP menurut Colbert, et.al. (1999) dalam Erieska (2019) merupakan ukuran yang menjadi suatu pembeda antara Kantor Akuntan Publik besar dengan Kantor Akuntan Publik kecil berdasarkan dengan jumlah klien yang dikelola dan 
jumlah tenaga profesional berupa partner dan staf yang dimiliki dalam KAP tersebut. Ukuran KAP dalam penelitian ini besar kecilnya KAP dibedakan menjadi dua jenis KAP, yaitu KAP yang berafiliasi dengan big four dan KAP yang tidak berafiliasi dengan big four.

DeAngelo (1981) dalam Nindita \& Siregar (2013) menyatakan bahwa KAP besar (big four accounting firms) cenderung untuk melakukan audit dengan lebih berkualitas dibandingkan dengan KAP berukuran kecil (non big four accounting firms). Francis \& Yu (2009) dalam Nindita \& Siregar (2013) mendukung pernyataan tersebut dengan mengatakan bahwa ada hubungan yang positif antara ukuran KAP dengan kualitas audit. Francis \& Yu (2009) dalam Nindita \& Siregar (2013) berpendapat bahwa hanya KAP berukuran besar yang dapat menghasilkan audit berkualitas dengan menunjukkan kemampuan nya dalam membatasi perilaku manajemen laba dan menerbitkan laporan audit going concern. KAP besar juga diyakini lebih mampu menangkap sinyal akan penyelewengan keuangan yang terjadi dan kemungkinan pengungkapannya lebih besar (Darwin, 2012; Erieska, 2019; Widiastuty, 2010; Nadia, 2015). KAP yang terafiliasi big four dan non big four menunjukkan bahwa kantor akuntan publik yang terafiliasi big four cenderung mempunyai hasil audit yang lebih baik. Berdasarkan uraian tersebut, maka penulis menghipotesiskan:

H1 : Ukuran KAP berpengaruh positif terhadap kualitas audit

\section{Audit Fee}

Menurut Agoes (2012) dalam Erieska (2019) audit fee merupakan imbalan yang diberikan oleh klien atau imbalan diterima dari klien dalam bentuk uang atau barang atau bentuk lainnya untuk memperoleh perikatan dari pihak klien. Dengan kata lain, audit fee merupakan biaya yang diberikan oleh perusahaan kepada seorang auditor atas imbalan jasa yang telah diberikan oleh auditor tersebut. Besaran fee yang diberikan oleh perusahaan beragam tergantung kepada bagaimana kompleksitas perusahaan yang akan diaudit tersebut (Erieska, 2019).

Besarnya audit fee yang diterima oleh auditor dianggap dapat mempengaruhi kualitas audit yang dihasilkan. Besarnya fee yang diterima oleh auditor dalam melaksanakan prosedur audit tergantung pada risiko penugasan, kompleksitas, jasa yang diberikan, tingkat keahlian yang diperlukan untuk melakukan jasa tersebut, struktur biaya KAP yang bersangkutan serta pertimbangan-pertimbangan profesional lainnya (Mulyadi, 2014: 63-64 dalam Damayanti, 2019).

Fee yang tinggi mampu mendorong peningkatan kemampuan auditor dan kinerjanya sehingga hal tersebut diharapkan dapat menghasilkan audit yang lebih 
berkualitas (Damayanti, 2019). Pemberian fee yang tinggi kepada auditor juga akan memperluas prosedur audit yang dilakukan sehingga kecurangan yang terjadi pada perusahaan dapat terdeteksi (Yanti, 2018 dalam (Damayanti, 2019). Berdasarkan uraian tersebut, maka penulis menghipotesiskan:

H2 : Audit fee berpengaruh positif terhadap kualitas audit

\section{Ukuran Perusahaan}

Perusahaan besar memiliki manajemen yang lebih berpengalaman serta sistem pengendalian internal yang lebih baik dibandingkan perusahaan yang lebih kecil atau perusahaan yang relative masih baru, sehingga perusahaan besar akan menghasilkan audit yang lebih berkualitas dibandingkan perusahaan kecil (Paramita \& Latrini, 2015). Sistem pengendalian internal yang dilaksanakan oleh manajemen perusahaan bertujuan untuk memastikan seluruh kegiatan perusahaan sudah dilakukan dengan benar dan sesuai dengan ketentuan yang berlaku (Panjaitan, 2018).

Adanya sistem pengendalian internal yang baik dalam perusahaan yang besar akan meningkatkan kualitas audit yang dihasilkan, karena dengan sistem pengendalian internal yang baik akan memberikan kemudahan untuk auditor dalam memperoleh informasi yang dibutuhkan. Begitu pula sebaliknya sistem pengendalian internal yang lemah akan menurunkan kualitas audit yang dihasilkan karena kelemahan sistem pengendalian internal membuat auditor harus bekerja lebih keras (Buchori \& Budiantoro, 2019). Berdasarkan uraian tersebut, maka penulis menghipotesiskan:

H3 : Ukuran perusahaan berpengaruh positif terhadap kualitas audit. 


\section{KERANGKA PEMIKIRAN}

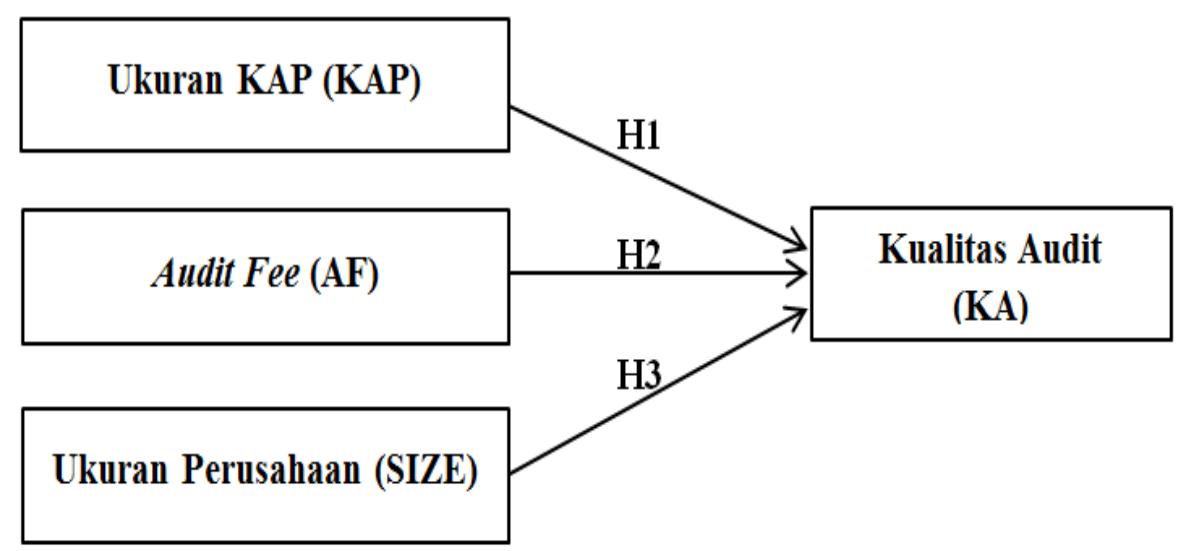

Gambar 1. Kerangka Penelitian

\section{METODOLOGI PENELITIAN}

\section{Populasi dan Sampel Penelitian}

Penelitian ini menggunakan populasi perusahaan manufaktur sektor industri barang konsumsi yang terdaftar di BEI periode 2015 - 2019. Teknik pemiihan sampel menggunakan purposive sampling, dengan kriteria sebagai berikut:

Tabel 1. Proses Pemilihan Sampel

\begin{tabular}{clc}
\hline No & \multicolumn{1}{c}{ Kriteria } & Jumlah \\
\hline 1 & $\begin{array}{l}\text { Total perusahaan manufaktur sektor industri barang konsumsi terdaftar } \\
\text { di (BEI) periode 2015 - 2019 }\end{array}$ & 100 \\
2 & $\begin{array}{l}\text { Total perusahaan manufaktur yang tidak mempublikasikan laporan } \\
\text { keuangan yang telah diaudit laporan tahunan secara konsisten pada } \\
\text { periode 2015 - 2019. }\end{array}$ & $(15)$ \\
3 & $\begin{array}{l}\text { Total perusahaan yang melakukan penghapusan pencatatan (delisting) } \\
\text { dari BEI selama periode 2015 - 2019 }\end{array}$ & 0 \\
4 & $\begin{array}{l}\text { Total perusahaan yang tidak mengungkapkan besarnya audit fee pada } \\
\text { publikasi selama periode 2015 - 2019 }\end{array}$ & $(60)$ \\
5 & $\begin{array}{l}\text { Total sampel perusahaan berdasarkan kriteria 25 } \\
6\end{array}$ & 25 \\
\hline
\end{tabular}

\section{Model Penelitian}

Metode analisis regresi logistik digunakan dalam penelitian ini karena penggunaan variabel dummy pada variabel dependen. Metode analisis regresi ini sesuai untuk penelitian dengan variabel dependen yang bersifat kategorikal (nominal atau non metrik) serta kombinasi antara metrik dan non metrik pada variabel independennya (Wicaksono, 2019). Model untuk regresi logistik sebagai berikut :

$$
\mathrm{KA}=\mathbf{a}+\beta 1 \mathrm{KAP}+\beta 2 \mathrm{AF}+\boldsymbol{\beta 3} \text { SIZE }+\varepsilon
$$


Keterangan:
$\mathrm{KA}=$ Kualitas Audit
$\mathrm{a}=$ Konstanta
KAP $=$ Ukuran KAP
$\mathrm{AF} \quad=$ Audit Fee
SIZE = Ukuran Perusahaan
$\varepsilon \quad=$ Error (residual)

\section{Operasionalisasi Variabel}

\section{Kualitas Audit}

Kualitas audit dalam penelitian ini menggunakan pengukuran berdasarkan earnings benchmark yang mengacu pada penelitian yang dilakukan oleh (Wicaksono, 2019). Earnings surprise benchmark adalah sebuah ukuran yang dikembangkan oleh oleh Carey dan Simnett (2006) untuk mengukur sebuah kualitas audit. Pengukuran kualitas audit disini terkait dengan manajemen laba yang dilakukan oleh perusahaan, apakah auditor dapat menemukan serta melakukan pelaporan terhadap manajemen laba yang dilakukan oleh perusahaan. Pengukuran kualitas audit menggunakan Earnings benchmark dilakukan dengan cara melihat apakah ROA terdapat di dalam benchmark atau tidak. Jika ROA berada didalam benchmark $(\mu-\sigma<\mathrm{ROA}<\mu+\sigma)$ maka menandakan bahwa kualitas audit baik. Sedangkan jika ROA berada diluar benchmark (ROA $>\mu+\sigma)$ atau $(\mathrm{ROA}<\mu-\sigma)$ maka menandakan kualitas audit buruk. Dimana $\mu$ adalah rata-rata ROA seluruh perusahaan sampel dan $\sigma$ adalah standard deviasinya (Wicaksono, 2019).

Pengukuran kualitas audit dengan variabel dummy, yaitu pemberian nilai 1 jika kualitas audit baik, sedangkan kualitas audit yang buruk akan diberikan nilai 0 . Variabel ini dilambangkan dengan KA. $\mu$ dan $\sigma$ dihitung dari sampel. Pengukuran kualitas audit sebagai berikut :

MEET_BE $=1$ laba berada dalam rentang nilai yang normal dimana $(\mu-\sigma$ $<\operatorname{ROA}<\mu+\sigma)$

MEET_BE $=0$ untuk ROA $>\mu+\sigma$ di mana laba melebihi earning benchmarkatau ROA < $\mu-\sigma$ dimana rugi melebihi earning benchmark, yang menunjukkan kualitas audit yang 


\section{Ukuran Kantor Akuntan Publik (KAP)}

Ukuran Kantor Akuntan Publik (KAP) merupakan pengukuran yang digunakan untuk menentukan besar atau kecilnya suatu KAP (Damayanti, 2019). Dalam penelitian ini pengukuran besar kecilnya KAP dibedakan menjadi dua kelompok, yaitu KAP yang berafiliasi dengan big four dan KAP yang tidak berafiliasi dengan big four (Rifai, 2019). Penggunaan Variabel dummy digunakan untuk mengukur variabel ukuran KAP. Jika perusahaan menggunakan jasa audit KAP big four maka akan diberi nilai 1 , dan sebaliknya jika perusahaan tidak menggunakan jasa audit KAP big four untuk laporan keuangannya maka akan diberi nilai 0 (Heryanto et al., 2017)

\section{Audit Fee}

Audit Fee merupakan imbalan yang diberikan oleh perusahaan kepada seorang auditor atas jasa yang telah dilakukan dalam mengaudit laporan keuangan perusahaan. Besar kecilnya fee yang diterima oleh auditor tergantung dari risiko penugasan, kompleksitas jasa yang diberikan, tingkat keahlian yang diperlukan untuk melaksanakan jasa tersebut, struktur biaya KAP yang bersangkutan (Damayanti, 2019). Dalam penelitian ini audit fee diproksikan pada professional fees yang tertera dalam laporan keuangan perusahaan atau laporan tahunan perusahaan. Variabel audit fee ini diukur dengan menggunakan logaritma natural dari informasi professional fees (Rifai, 2019). Rumus untuk mengukur variabel audit fee sebagai berikut :

$$
\text { Audit Fee }=\operatorname{Ln}(\text { fee })
$$

\section{Ukuran Perusahaan}

Ukuran perusahaan merupakan ukuran besar kecilnya aset yang dimiliki oleh perusahaan (Heryanto et al., 2017). Variabel ukuran perusahaan diukur dengan logaritma natural total aset perusahaan pada akhir periode (Heryanto et al., 2017). Data total aset diperoleh langsung dari neraca perusahaan. Rumus untuk mengukur variabel ukuran perusahaan sebagai berikut :

$$
\text { Ukuran Perusahaan }=\text { Ln (total aset) }
$$




\section{PEMBAHASAN}

\section{Statistik Deskriptif}

Dari hasil analisis deskriptif statistic diperoleh hasil bahwa sebanyak 22,4\% perusahaan memiliki kualitas audit yang tidak baik, yaitu sebanyak 28 perusahaan, sedangkan sebesar $77,6 \%$ sisanya memiliki kualitas audit yang baik atau dengan total 97 perusahaan dari total sampel penelitian $100 \%$ atau berjumlah 125 perusahaan.

Tabel 2. Kualitas Audit

\begin{tabular}{lrrrr}
\hline & & & Valid & Cumulative \\
& Frequency & Percent & Percent & Percent \\
\hline Kualitas Tidak Baik & 28 & 22,4 & 22,4 & 22,4 \\
Kualitas Baik & 97 & 77,6 & 77,6 & 100,0 \\
Total & 125 & 100,0 & 100,0 & \\
\hline
\end{tabular}

Sumber : Output SPSS

Berdasarkan pengujian statistik deskriptif diperoleh hasil bahwa variabel audit fee (AF) menunjukkan nilai rata-rata 22,88 dengan nilai standar deviasinya sebesar 1,87. Nilai minimum audit fee sebesar 18,08 dan nilai maksimum sebesar 27. Hasil analisis yang diperoleh dari uji statistik deskriptif terhadap variabel ukuran perusahaan menunjukkan nilai rata-rata 28,71 dengan nilai standar deviasinya sebesar 1,75 . Nilai minimum sebesar 21,04 dan nilai maksimum sebesar 32,20.

\section{Tabel 3. Analisis Deskriptif}

\begin{tabular}{lcrrrr}
\hline & n & Minimum & Maximum & Mean & Std. Deviation \\
\hline Audit Fee & 125 & 18,08 & 27,46 & 22,8809 & 1,87755 \\
Ukuran Perusahaan & 125 & 21,04 & 32,20 & 28,7100 & 1,75230 \\
\hline Sumber : Output SPSS & & & & &
\end{tabular}

Sumber : Output SPSS

Hasil analisis atas variabel ukuran KAP yang ditunjukkan dalam Tabel 4 menunjukkan bahwa dari seluruh sampel yang digunakan sebesar $56 \%$ atau sebesar 70 perusahaan diaudit oleh KAP yang tidak berafiliasi dengan big four dan sebesar $44 \%$ atau sebesar 55 perusahaan diaudit oleh KAP yang berafiliasi dengan big four dari total sampel penelitian $100 \%$ atau berjumlah 125 perusahaan 
Tabel 4. Variabel Ukuran KAP

\begin{tabular}{lrrrr}
\hline & Frequency & Percent & $\begin{array}{r}\text { Valid } \\
\text { Percent }\end{array}$ & $\begin{array}{r}\text { Cumulative } \\
\text { Percent }\end{array}$ \\
\hline KAP non big 4 & 70 & 56,0 & 56,0 & 56,0 \\
KAP big 4 & 55 & 44,0 & 44,0 & 100,0 \\
Total & 125 & 100,0 & 100,0 & \\
\hline
\end{tabular}

Sumber : Output SPSS

\section{Uji Asumsi Dasar}

\section{a. Uji Kelayakan Model}

Pada Tabel 5 dapat dilihat nilai signifikansi dari hasil pengujian sebesar 0,787 yang artinya lebih besar dari 0,05 sehingga $\mathrm{HO}$ diterima dan model regresi layak untuk digunakan. Kesimpulan dari data tersebut adalah bahwa data tepat dan cocok dalam melakukan pengujian hipotesis serta tidak adanya perbedaan yang nyata antara klasifikasi yang diprediksi dengan yang diamati.

\begin{tabular}{|c|c|c|c|}
\hline \multicolumn{4}{|c|}{ Hosmer And Lemeshow Test } \\
\hline Step & Chi-square & $\mathrm{df}$ & Sig. \\
\hline 1 & 4,718 & 8 & ,787 \\
\hline
\end{tabular}

\section{b. Uji Keseluruhan Model}

Informasi yang diperoleh dari hasil pengujian keseluruhan model berdasarkan pada tabel 6 dan 7 menunjukkan bahwa pengujian dilakukan dengan membandingkan nilai antara -2 Log Likelihood (-2LL). Dari tabel di atas diketahui bahwa nilai -(-2LL) awal (Block Number $=0$ ) sebesar 132,981 dan nilai $(2 \mathrm{LL})$ akhir (Block Number $=1$ ) sebesar 113,650 . Dari tabel hasil pengujian keseluruhan model dapat dilihat terjadi penurunan pada nilai (-2LL). Penurunan nilai pada (-2LL) yang terjadi menunjukkan bahwa model regresi yang lebih baik atau dapat dikatakan model yang dihipotesiskan fit dengan data.

Tabel 6. Hasil Uji Keseluruhan Model

\begin{tabular}{|c|c|c|c|}
\hline \multicolumn{4}{|c|}{ Iteration History ${ }^{\mathrm{a}, \mathrm{B}, \mathrm{C}}$} \\
\hline Iteration & & $\begin{array}{l}-2 \text { Log } \\
\text { likelihood }\end{array}$ & $\begin{array}{c}\text { Coefficients } \\
\text { Constant }\end{array}$ \\
\hline Step 0 & 1 & 133,408 & 1,104 \\
\hline & 2 & 132,982 & 1,238 \\
\hline & 3 & 132,981 & 1,242 \\
\hline & 4 & 132,981 & 1,243 \\
\hline
\end{tabular}


Tabel 7. Hasil Uji Keseluruhan Model

\begin{tabular}{|c|c|c|c|c|c|c|}
\hline \multicolumn{7}{|c|}{ Iteration History $^{a, b, c, d}$} \\
\hline \multirow[b]{2}{*}{ Iteration } & & \multirow{2}{*}{$\begin{array}{l}-2 \text { Log } \\
\text { likelihood }\end{array}$} & \multirow[b]{2}{*}{ Constant } & \multicolumn{2}{|c|}{ Coefficients } & \multirow[b]{2}{*}{ SIZE } \\
\hline & & & & KAP & $\mathrm{AF}$ & \\
\hline Step 1 & 1 & 117,574 & 621 &,- 933 &,- 194 & 186 \\
\hline & 2 & 113,841 & 1,493 & $-1,298$ & -324 & 275 \\
\hline & 3 & 113,650 & 1,890 & $-1,398$ &,- 364 & 299 \\
\hline & 4 & 113,650 & 1,924 & $-1,406$ &,- 367 & ,300 \\
\hline & 5 & 113,650 & 1,924 & $-1,406$ & -367 & 300 \\
\hline
\end{tabular}

Sumber : Output SPSS

\section{c. Hasil Uji Koefisien Determinasi (Nagelkerke R Square)}

Pada hasil model summary pada tabel 8 memberikan nilai Nagelkerke R Square sebesar 0,219. Berdasarkan hasil tersebut berarti variabilitas variabel dependen yang dapat dijelaskan oleh variabilitas variabel independen sebesar $21,9 \%$ sedangkan sisanya $78,1 \%$ dijelaskan oleh variabel lain yang tidak digunakan dalam penelitian ini.

\section{Tabel 8. Hasil Uji Koefisien Determinasi}

\begin{tabular}{|c|c|c|c|}
\hline \multicolumn{4}{|c|}{ Model Summary } \\
\hline Step & -2 Log likelihood & Cox \& Snell R Square & Nagelkerke R Square \\
\hline 1 & $113,650^{a}$ & 143 & ,219 \\
\hline
\end{tabular}

\section{Analisis Regresi Logistik}

Hasil pengujian menggunakan regresi logistic dapat dilihat pada Tabel 8. Pada table tersebut dapat dilihat bahwa: Ukuran KAP (KAP) berpengaruh positif dan signifikan terhadap kualitas audit sehingga H1 diterima. Audit fee (AF) berpengaruh positif dan signifikan terhadap kualitas audit sehingga H2 diterima. Selanjutnya, Ukuran perusahaan (SIZE) tidak berpengaruh terhadap kualitas audit sehingga H3 ditolak.

Tabel 9. Hasil Analisis Regresi Logistik

\begin{tabular}{llrrrrrr}
\hline & & & & & & & \\
& & \multicolumn{1}{c}{ B } & \multicolumn{1}{c}{ S.E. } & \multicolumn{1}{c}{ Wald } & df & \multicolumn{1}{c}{ Sig. } & $\operatorname{Exp(B)}$ \\
\hline Step 1 ${ }^{\text {a }}$ & KAP & $-1,406$ &, 545 & 6,667 & 1 &, 010 &, 245 \\
& AF &,- 367 &, 185 & 3,924 & 1 &, 048 &, 693 \\
& SIZE &, 300 &, 164 & 3,358 & 1 &, 067 & 1,350 \\
& Constant & 1,924 & 4,201 &, 210 & 1 &, 647 & 6,846 \\
\hline
\end{tabular}

Sumber: Output SPSS 


\section{Interpretasi Hasil Penelitian}

\section{Pengaruh Ukuran KAP terhadap Kualitas Audit}

Dalam hasil di atas menunjukkan bahwa ukuran KAP berpengaruh positif dan signifikan terhadap kualitas audit. Hasil penelitian ini sejalan dengan penelitian yang dilakukan oleh peneliti Ivan (2020) yang menyatakan bahwa ukuran KAP berpengaruh positif terhadap kualitas audit. Ukuran KAP berpengaruh positif terhadap kualitas audit karena diduga auditor yang tergabung di KAP big 4 memiliki integritas dan kecakapan yang lebih baik serta memiliki karakteristik yang bisa dikaitkan dengan peningkatan kualitas audit dengan adanya pelatihan, pengalaman dan pengakuan internasional (Nadia, 2015). KAP berukuran besar juga lebih fokus untuk menjaga reputasinya sehingga dapat menghasilkan audit yang berkualitas (Erieska, 2019). Dengan demikian, dari hasil penelitian ini mendukung teori bahwa auditor yang kompeten akan dapat memitigasi masalah konflik kepentingan dalam teori keagenan sebagai bentuk monitoring terhadap agent yang dilakukan oleh principal.

\section{Pengaruh Audit Fee terhadap Kualitas Audit}

Hasil Penelitian membuktikan bahwa audit fee memiliki pengaruh positif dan signifikan terhadap kualitas audit. Hal itu disebabkan karena audit fee yang tinggi akan meningkatkan intensif bagi auditor untuk merencanakan kualitas audit yang lebih tinggi. Hasil penelitian ini sejalan dengan penelitian yang dilakukan oleh peneliti Wicaksono (2019) yang menyatakan bahwa audit fee berpengaruh positif terhadap kualitas audit. Audit fee yang tinggi menghasilkan kualitas audit yang baik pula, begitu sebaliknya. Kualitas audit yang baik tercipta karena kinerja auditor yang dibutuhkan lebih profesional dalam mengaudit laporan keuangan klien (Erieska, 2019).

\section{Pengaruh Ukuran Perusahaan Klien terhadap Kualitas Audit .}

Dalam penelitian ini variabel ukuran perusahaan tidak berpengaruh terhadap kualitas audit. Hal ini menunjukkan besar kecilnya perusahaan belum tentu mempengaruhi kualitas audit. Perusahaan besar maupun perusahaan kecil diduga samasama memilki sistem pengendalian internal yang telah dijalankan dengan baik, sehingga tidak ada perbedaan diantara keduanya terkait kualiats audit yang dihasilkan. Hasil penelitian ini sejalan dengan penelitian Paramita \& Latrini (2015) yang mengatakan bahwa ukuran perusahaan tidak berpengaruh terhadap kualitas audit. 


\section{KESIMPULAN}

Berdasarkan hasil pengujian dan pembahasan yang dijelaskan pada bab sebelumnya, maka dapat disimpulkan bahwa Ukuran Kantor Akuntan Publik (KAP) berpengaruh positif terhadap kualitas audit. Hal ini karena diduga auditor yang tergabung di KAP big 4 memiliki integritas dan kecakapan yang lebih baik serta memiliki karakteristik yang bisa dikaitkan dengan peningkatan kualitas audit dengan adanya pelatihan, pengalaman dan pengakuan internasional. Selanjutnya, Audit fee berpengaruh positif terhadap kualitas audit. Hal ini disebabkan karena tingginya feeyang diberikan akan meningkatkan intensif auditor dalam melakukan perencanaan kualitas audit yang lebih tinggi. Fee yang tinggi juga dianggap berhubungan dengan upaya yang besar pula dari auditor untuk dapat menemukan bukti memadai sebelum memberikan opininya. Namun, Ukuran perusahaan tidak berpengaruh terhadap kualitas audit yang dihasilkan. Besar kecilnya perusahaan tidak dapat mempengaruhi kualitas audit.

Dari hasil penelitian ini diharapkan kedepannya untuk Kantor Akuntan Publik (KAP) dapat meningkatkan kualitasnya sehingga mampu bersaing dengan KAP yang berafiliasi dengan big four untuk dapat menghasilkan kualitas audit yang baik. Kantor Akuntan Publik (KAP) juga diharapkan dapat meningkatkan kualitas auditor yang bekerja dengan memberikan pelatihan serta mempertimbangkan pengalaman yang dimiliki sehingga auditor tersebut dapat memiliki integritas dan kecakapan yang baik serta karakteristik yang bisa dikaitkan dengan peningkatan kualitas audit seperti yang dimiliki oleh auditor yang tergabung di dalam Kap big four.

Untuk perusahaan diharapkan dapat memperhatikan kualitas sistem pengendalian internal perusahaan serta selanjutnya meningkatkan kualitas dari sistem pengendalian internal tersebut agar dapat meningkatkan kualitas audit.

Untuk auditor diharapkan dapat memperhatikan faktor-faktor yang dapat mempengaruhi kualitas audit dan selanjutnya memperhatikan faktor tersebut untuk meningkatkan kualitas audit. Auditor diharapkan dapat meningkatkan integritas dan kecakapan sehingga mampu bersaing dengan auditor yang tergabung dengan KAP big four dalam menghasilkan kualitas audit yang baik dan menetapkan fee audit yang tepat dengan mempertimbangkan tahapan-tahapan dalam perencanaan, pelaksanaan, serta faktor lain sesuai dengan Peraturan Pengurus Nomor 2 Tahun 2016 Tentang Penentuan Imbalan Jasa Audit Laporan Keuangan, yang dikeluarkan oleh Ikatan Akuntan Publik Indonesia (IAPI). Diharapkan auditor dapat meminimalisir adanya pengaruh-pengaruh tersebut baik yang berasal dari dalam maupun dari luar dari dirinya untuk dapat meningkatkan kualitas audit. 
Penelitian ini memiliki keterbatasan, antara lain tahun pengamatan dari 2015 sampai dengan 2019. Untuk penelitian lebih lanjut dapat memperpanjang periode pengamatan agar dapat memperoleh hasil yang lebih baik. Selanjutnya dalam mengukur variabel ukuran perusahaan, penulis menggunakan logaritma natural dari Total Asset. Untuk penelitian selanjutnya bisa menggunakan pengukuran sistem pengendalian internal, sehingga diharapkan bisa memberikan hasil yang signfikan. Penelitian ini juga memiliki keterbatasan karena belum menambah variabel kontrol dalam model persamaan, sehingga untuk penelitian selanjutnya bisa menambahkan variabel kontrol baik faktor internal (seperti leverage) maupun faktor eksternal (misalnya kondisi perekonomian) yang dapat mempengaruhi kualitas audit.

\section{DAFTAR PUSTAKA}

Agusti, R. \&, \& Pertiwi, N. P. (2013). Pengaruh Kompetensi, Independensi, dan Profesionalisme terhadap Kualitas Audit (Studi Empiris pada Kantor Akuntan $\begin{array}{llll}\text { Publik Se Sumatera). JURNAL EKONOMI, } 21 . & \end{array}$ https://doi.org/10.22441/tekun.v8i1.5528

AL-Qatamin, K. I., \& Salleh, Z. (2020). Audit Quality: A Literature Overview and Research Synthesis. IOSR Journal of Business and Management (IOSR-JBM), 22(2), 5666. https://doi.org/10.9790/487X-2202025666

Buchori, A., \& Budiantoro, H. (2019). Pengaruh Ukuran Perusahaan Klien, Audit Tenure, dan Spesialisasi Auditor Terhadap Kualitas Audit. Jurnal Pajak, Akuntansi, Sistem Informasi, Dan Auditing, 1 (1), 22-39.

Calocha, R., \& Herwiyanti, E. (2020). Factors that affect audit quality. Journal of Contemporary Accounting, 2 (1), 35-48. https://doi.org/10.20885/jca.vol2.iss1.art4

Damayanti, N. S. (2019). Fee Audit, Audit Tenure, Ukuran Kap terhadap Kualitas Audit (Studi Empiris pada Perusahaan Manufaktur yang Terdaftar di Bursa Efek Indonesia Periode 2014-2018). Magelang: Universitas Muhammadiyah Magelang.

Darwin. (2012). Analisis Perbedaan Kualitas Audit KAP Big 4 dan KAP Second Tier dinilai dari Independensi Auditor, Manajemen Laba, dan Nilai Relevansi Laba. Skripsi. Fakultas Ekonomi. Universitas Indonesia.

Erieska, L. A. (2019). Pengaruh Size KAP dan Fee Audit terhadap Kualitas Audit dengan Rotasi Audit sebagai Variabel Intervening (Studi Empiris pada Perusahaan Manufaktur yang Tercatat di Bursa Efek Indonesia 2014-2017). In Jurnal Mahasiswa Magister Akuntansi (Vol. 4, Issue 1).

Gustiawan, M. D. (2015). Pengaruh Kompetensi, Independensi, Pengalaman Auditor, dan Etika Auditor terhadap Kualitas Audit. Universitas Sebelas Maret Surakarta.

Heryanto, H., Laela, N., \& Dewi, R. R. (2017). Faktor-Faktor Yang Mempengaruhi Kualitas Audit. EBA Journal: Journal Economics, Bussines and Accounting, 5(1), 50-63. 
https://doi.org/10.32492/eba.v5i1.712

Ivan, M. (2020). Pengaruh Audit Fee , Rotasi Kap Dan Reputasi Auditor Terhadap Kualitas Audit ( Studi Empiris Pada Perusahaan Syariah Yang Terdaftar Di Jakarta Islamic Index Tahun 2014-2018). In STIE MULTI DATA PALEMBANG. Palembang: STIE Multi Data Paelembang.

Kristanti, F. T. (2014). Review of Agency Theory. In Fakultas Ekonomi dan Bisnis Universitas Telkom Bandung.

Muhamad Taqi, M., Rahmawati, R., Bandi, B., Murni, S., \& Warsina, W. (2020). Audit Quality Attibutes and Client Factors. AFRE (Accounting and Financial Review), 3(1), 1-13. https://doi.org/10.26905/afr.v3i1.3884

Nadia, N. F. (2015). Pengaruh Tenur KAP, Reputasi KAP dan Rotasi KAP terhadap Kualitas Audit. Jurnal Akuntansi Bisnis, XIII(26), 113-130.

Nindita, C., \& Siregar, S. V. (2013). Analisis Pengaruh Ukuran Kantor Akuntan Publik Terhadap Kualitas Audit di Indonesia. Jurnal Akuntansi Dan Keuangan, 14 (2). https://doi.org/10.9744/jak.14.2.91-104

Nurhayati, S., \& Dwi, S. (2015). Pengaruh Rotasi KAP, Audit Tenure, Dan Reputasi KAP Terhadap Kualitas Audit Pada Perusahaan Manufaktur. Jurnal Akuntansi Aktual, $3(2), 165-174$.

Oktavinarni, N. P. (2018). Pengaruh Kompetensi, Independensi, dan Due Profesional Care Auditor Terhadap Kualitas Audit Pada KAP Di Wilayah Surabaya Timur. 109.

Panjaitan, N. U. (2018). Pengaruh Audit Tenure dan Kualitas Sistem Pengendalian Internal Terhadap Kualitas Audit (Studi Empiris Pada Perusahaan Manufaktur di Bursa Efek Indonesia .... Universitas Sumatera Utara.

Paramita, N. K. A., \& Latrini, N. M. Y. (2015). Pengaruh Ukuran Perusahaan, Umur Publikasi, Masa Perikatan Audit, Pergantian Manajemen Pada Kualitas Audit. EJurnal Akuntansi Universitas Udayana, 13 (1), 142-156.

Rifai, M. (2019). Pengaruh Audit Tenure, Audit Fee, Rotasi Kap dan Ukuran Kap Terhadap Kualitas Audit (Pada Perusahaan Manufaktur Sektor Industri Barang Konsumsi Yang Terdaftar Di Bursa Efek Indonesia Tahun 2016-2018).

Rizaldi, S. (2017). Pengaruh Audit Tenure, Reputasi Auditor, Komite Audit Dan Fee Audit Terhadap Kualitas Audit (Studi Empiris Pada Perusahaan Yang Terdaftar Di Indeks KOMPAS100 Pada BEI Tahun 2012-2016). Universitas Jambi.

Sari, M. M. E. (2014). Pengaruh Audit Tenure, Ukuran KAP, dan Ukuran Perusahaan terhadap Kualitas Audit pada Perusahaan Manufaktur sektor Barang Konsumsi yang Terdaftar di Bursa Efek Indonesia Periode 2011-2013. In Universitas Nusantara PGRI Kediri. Universitas Nusantara PGRI Kediri.

Tandiotong, M. (2015). Kualitas Audit dan Pengukurannya. Alfabeta.

Wicaksono, R. A. (2019). Pengaruh Ukuran Perusahaan, Fee Audit, Audit Tenure, Rotasi KAP terhadap Kualitas Audit (Studi Empiris pada Perusahaan Manufaktur Industri Sektor Barang Konsumsi di Bursa Efek Indonesia Periode 2016-2018). In Universitas Islam Indonesia. Yogyakarta: Universitas Islam Indonesia.

Widiastuty, E. (2010). Pengukuran Kualitas Audit: Sebuah Esai. Jurnal IImiah Akuntansi Dan Bisnis, 1-43.

Yakin, F. E. (2020). Pengaruh Audit Tenure, Audit Fee, dan Ukuran Perusahaan Klien 
Indriyani dan Meini - Pengaruh Ukuran KAP, Audit Fee, Dan Ukuran Perusahaan terhadap...

terhadap Kualitas Audit (Studi Empiris pada Perusahaan Manufaktur yang Terdaftar di Bursa Efek Indonesia Tahun 2016-2018). Surabaya: Universitas Negeri Sunan Ampel.

Yolanda, Stephanie; Arza, F. I. ; H. (2019). Pengaruh Audit Tenure, Komite Audit Dan Audit Capacity Stress Terhadap Kualitas Audit (Studi pada perusahaan manufaktur yang terdaftar di Bursa Efek Indonesia periode 2015-2017). Jurnal Eksplorasi Akuntansi, 1 (2), 543-555. 